\title{
Ferrocement Panels under High Velocity Impact by Incorporating Waste Foundry Sand
}

\author{
Balraj E. Karpe, Darshan G. Gaidhankar, Mrudula S. Kulkarni.
}

\begin{abstract}
Ferrocement is widely used because of its excellent behavior pf ferrocement under flexural, and impact strength. Ferrocement also has excellent mechanical properties. In this study, total 16 ferrocement panels were modelled of M50 grade of concrete. The thickness of ferrocement panels considered is $15 \mathrm{~mm}, 20 \mathrm{~mm}$ and $25 \mathrm{~mm}$. Galvanized welded mesh is used as reinforcement in panels. This wire-meshes were layered in 2, 3, 4 and 5 layers. High velocity impact test is done by $A k-47$ bullet striking with a velocity of 150, 250, 350, 450, 550, 650 and $750 \mathrm{~m} / \mathrm{s}$ for each panel. All this panels were modelled in design modeler of Ansys explicit Dynamics. Deformation, Equivalent Stress and Normal Stress of all the panels are evaluated and compared by analyzing in ANSYS Explicit Dynamics. From the past researches and the conclusions made by these researches, we can see positive chance in the utilization of waste foundry sand in construction field. As these results gives the great emphasis towards the development on environment friendly and economical constructions.
\end{abstract}

Keywords: ANSYS WB 19.2, Ferrocement, Flexural Strength, Impact Strength, Waste Foundry Sand.

\section{INTRODUCTION}

$\mathrm{F}$ errocement is constructed as a thin wall reinforced concrete made up with hydraulic cement mortar which is reinforced with closely spaced layers of continuous and tiny sized wire-mesh. The materials used to make wire-mesh can be metals or different alloys.

Being a developing country and economy, the level of infrastructure development is raised in India. RCC has been the most used material in construction industry all over the world. However, rates of materials used in RCC are increasing day by day. Also, availability of materials is one of the major issues construction industry is currently facing. So ferrocement can be perfect substitute for RCC in some structures which provides same or more strength at low price. Ferrocement consist of mortar reinforced by wire mesh to form component having comparatively small thickness, high sturdiness and resilience which results into high strength and rigidity. To analyze the response of ferrocement in unconventional applications and numerical simulations, the

Revised Manuscript Received on June 15, 2020.

* Correspondence Author

Balraj E. Karpe, Second Year M.Tech Student, MIT World Peace University, Pune, India. Email: balrajkarpe1@gmail.com

Prof. D. G. Gaidhankar, Associate Professor, MIT World Peace University, Pune, India. Email: darshan.gaidhankar@mitwpu.edu.in

Prof. Dr. Mrudula S. Kulkarni, Head of School, School of Civil Engineering, MIT World Peace University, Pune, India.

(C) The Authors. Published by Blue Eyes Intelligence Engineering and Sciences Publication (BEIESP). This is an open access article under the CC BY-NC-ND license (http://creativecommons.org/licenses/by-nc-nd/4.0/)
Finite Element Method (FEM) has got necessary ends up recently. To provide realistic outcomes which replicates real-world simulations, a constitutive model of ferrocement component can be made.

Ferrocement shows more ductility as compared to reinforced concrete because in ferrocement, the reinforcement is uniformly distributed over both directions of element. Thus, ferrocement element shows more resistance to impact loads compared to RCC element. Any structure goes under impact loading many times throughout it's useful life.

Concrete is composed of cement, fine aggregate i.e. sand, coarse aggregate i.e. gravel/crushed stones, water, etc. is heart of any construction work. Out of which fine aggregate is one of the main constituents which is been used in vast quantity all over the world. The worldwide consumption of fine aggregate is very high and this consumption is also increasing day by day. This increasing demand is raised as a question in front of the construction industry.

At the same time, many industries have developed on large scale. Metal casting industry is one of them. Metal industry has many by-products which are discarded as wastes from industry after their useful life. This waste products can cause environmental problems as many of them are non-biodegradable. Used foundry sand is one of the waste products from metal casting industry. This waste foundry sand can be used in concrete as replacement for fine aggregate. This could help in overcoming this increasing fine aggregate demand.

Foundry sand is uniform, very fine, high quality silica sand. It is used to make moulds for casting metal components. After many casting cycles, this burnt foundry sand is no longer used for casting and removed as waste product from the metal casting industry. This waste foundry sand can be used as fine aggregate in construction industry. This replacement of sand by waste foundry sand could prove environment friendly, economical and could also enhance properties of concrete.

\section{OBJECTIVES}

- Effect of panel thickness on total deformation, equivalent (von mises) stress, and normal stress of ferrocement panel under hight velocity bullet impact.

- Effect of number of wire mesh layers on total deformation, equivalent (von mises) stress, and normal stress of ferrocement panel under hight velocity bullet impact

- Effect of waste foundry sand on total deformation, equivalent (von mises) stress, and normal stress of ferrocement panel under hight velocity bullet impact 


\section{Ferrocement Panels under High Velocity Impact by Incorporating Waste Foundry Sand}

\section{PARAMETERS OF STUDY}

- Thickness of panels are taken as $15 \mathrm{~mm}, 20 \mathrm{~mm}$ and $25 \mathrm{~mm}$.

- Number of mesh layers for $15 \mathrm{~mm}$ panels are 2 and 3.

- Number of mesh layers for $20 \mathrm{~mm}$ panels are 2, 3 and 4.

- Number of mesh layers for $25 \mathrm{~mm}$ panels are 3, 4 and 5.

- For high velocity impact loading, Avtomat Kalashnikov (AK-47) Bullet of size $(7.76 \times 19) \mathrm{mm}$ is used.

- Impact loading is analysed with velocities $150 \mathrm{~m} / \mathrm{s}$, $250 \mathrm{~m} / \mathrm{s}, 350 \mathrm{~m} / \mathrm{s}, 450 \mathrm{~m} / \mathrm{s}, 550 \mathrm{~m} / \mathrm{s}, 650 \mathrm{~m} / \mathrm{s}$, and $750 \mathrm{~m} / \mathrm{s}$.

- Waste foundry sand is also used as 30\% replacement of fine aggregate in mortar.

\section{LITERATURE REVIEW}

Vema Reddy, S.Sridhar have investigated the performance of fresh and hardened properties of concrete incorporated with waste foundry sand in place of fine aggregate. They performed the test on the cubes and cylinders by replacing foundry sand by $20 \%-100 \%$. They concluded that, the compressive strength of the concrete is increased by $13 \%$ by the replacement of $20 \%$ of normal sand by waste foundry sand. Their results showed that both compressive strength and split tensile strength of concrete are increased up to $60 \%$ replacement of normal sand by waste foundry sand. After which it reduces up to $100 \%$ replacement.

Rahul Roy, Dr. V. Sairam have compared the strength characteristics of ferrocement panels with panels made with HDPE geogrids in their study. They made 4 trial mixes each containing $0 \%, 5 \%, 10 \%$, and $15 \%$ waste foundry sand. They concluded that the use of used foundry sand has been proved beneficial by replacing fine aggregate, this replacement material not only provides strength characteristics but also overcomes the problem of waste disposal.

Vipul D. Prajapati, Nilay Joshi, Jayeshkumar Pitroda investigated the behaviour of concrete by replacing used foundry sand in different proportion in concrete. They replaced fine aggregate by used foundry sand in the range of $0 \%, 10 \%, 30 \% \& 50 \%$ by weight for $\mathrm{M}-20$ grade concrete. They evaluated the compressive and flexural strength of concrete for curing period of 7, 14 and 28 days. They found increase in compressive and flexural strength of concrete with increases in used foundry sand up to 50\%. They also concluded that the maximum compressive and flexural strength is achieved at $50 \%$ replacement of natural fine aggregate with used foundry sand.

S.S.Jadhav, S.N.Tande, A.C.Dubal studied the effect of foundry sand as fine aggregate replacement on the compressive strength, split tensile strength and modulus of elasticity of concrete having mix proportions of M 25 grade. The percentages of replacements were $0 \%, 10 \%, 30 \%, 50 \%$, and $100 \%$ by weight of fine aggregate. They concluded that compressive strength of concrete with partial replacement of Used Foundry Sand ( $0 \%$ to 30\%)has increased up to 30\% replacement and after that goes on decreasing as compared to concrete mix with natural sand.
Darshan G. Gaidhankar, Mrudula S. Kulkarni, Abhizer Akhtar have studied the effect of panel thickness, types of mesh, Different grades of mortar and types of fibres on deformation, equivalent stress and normal stress of panel under low velocity and high velocity impact loading. Total 6 types of panels were modeled for each M30, M40 and M50 grade of concrete. They considered thickness of ferrocement panel as $20 \mathrm{~mm}$ and $30 \mathrm{~mm}$. High velocity impact testing was done by AK-47 bullet striking with a velocity of $300 \mathrm{~m} / \mathrm{s}, 400$ $\mathrm{m} / \mathrm{s}, 500 \mathrm{~m} / \mathrm{s}, 600 \mathrm{~m} / \mathrm{s}$ and $700 \mathrm{~m} / \mathrm{s}$. They concluded that bullet impact loading shows that the penetration depth, normal stress and equivalent stress increases with increase in velocity of bullet. And all of the above parameters were decreases when thickness and grade of mortar increases.

Abdullah, Katsuki Takiguchi, Koshiro Nishimura and Shingo Hori investigated the behavior of ferrocement panels subjected to missile impact. They prepared 7 panel specimens of $750 \mathrm{~mm}^{2}$ with three different thicknesses, $80-\mathrm{mm}, 100-\mathrm{mm}$, and $120-\mathrm{mm}$. This panels were subjected to a hemispherical head of non-deformable type missile projectile. They observed that not only the missile perforation was prevented but also the damage area and the amount of flying concrete reduced significantly by increasing mesh reinforcement of smaller diameter.

\section{METHODOLOGY}

\section{A. Experimentation}

1) Cement

Ordinary Portland Cement of 53 grade which is locally available is used. Properties of cement were considered according to specifications given in IS: 456-2000 and IS 12269: 2013.

2) Fine Aggregate

Sand passing through $2.36 \mathrm{~mm}$ sieve obtained from natural river is used.

3) Waste Foundry Sand

Waste foundry sand available from local casting industry was used.

4) Admixture

Super plasticizing admixture Perm Plast PS-34 is used to produce self-compacting flowing high early strength mortar.

5) Mix Proportion

The mix proportion for mortar of cement: sand is taken as $1: 1.5$ with $\mathrm{W} / \mathrm{C}$ ratio as 0.38 .

6) Test Specimen

Total 40 cubes of size $(70 \times 70 \times 70) \mathrm{mm}$ were prepared and tested to determine maximum compression strength. Test specimens are categorized in two categories, 1. Mortar

2. 30\% WFSM (Waste Foundry Sand Mortar)

7) Result of experimental work

The experimental work include preparation and testing of cubes with normal mortar and mortar with fine aggregate replaced by waste foundry sand.

In trial mix, mix proportions as $1: 1.5,1: 1.75$ and $1: 2$ was taken. Water-Cement ratios of $0.36,0.38$ and 0.40 with $1 \%$ of admixture were taken. Maximum results were obtained for mix proportion of $1: 1.5$ and $\mathrm{W} / \mathrm{C}$ ratio of 0.38 . 
The Waste foundry sand is replaced by $10 \%, 20 \%, 30 \%$ and $40 \%$ by weight of fine aggregate.

From compressive strength test results, we found that replacement of sand by $30 \%$ with waste foundry sand gives maximum compressive strength

Table 1. Compressive strength of test specimen(28 days)

\begin{tabular}{|l|l|l|l|l|}
\hline \multirow{2}{*}{$\begin{array}{l}\text { Nr. } \\
\text { No. }\end{array}$} & Type & $\begin{array}{l}\text { Load } \\
\text { at } \\
\text { failure } \\
(\mathrm{Kg})\end{array}$ & $\begin{array}{l}\text { Compressive } \\
\text { strength } \\
\left(\mathrm{N} / \mathrm{mm}^{2}\right)\end{array}$ & $\begin{array}{l}\text { Avg. } \\
\text { Comp. } \\
\text { strength } \\
\left(\mathrm{N} / \mathrm{mm}^{2}\right)\end{array}$ \\
\hline 1 & $\begin{array}{l}\text { Conventional } \\
\text { mortar }\end{array}$ & 23600 & 48.63 & 48.93 \\
\cline { 3 - 4 } & 24100 & 49.18 & \\
\cline { 3 - 4 } & & 24000 & 48.97 & \multirow{2}{*}{64.21} \\
\hline 2 & $\begin{array}{l}\text { Mortar with } \\
\text { Waste }\end{array}$ & 31800 & 64.89 & \\
\cline { 3 - 4 } & foundry sand & 31200 & 63.67 & \\
\cline { 3 - 4 } & & 31400 & 64.08 & \\
\hline
\end{tabular}

\section{B. Material Properties}

- Compressive strength of mortar is taken as $53 \mathrm{MPa}$ which is an experimental data and $65 \mathrm{MPa}$ after replacing fine aggregate by waste foundry sand.

- Young's Modulus (E) and Poisson's ratio $(\mu)$ for material are taken as $20000 \mathrm{MPa}$ and 0.18 respectively.

- Diameter of wire used for wiremesh is taken as $1.2 \mathrm{~mm}$ with $15 \mathrm{mmx} 15 \mathrm{~mm}$ opening.

- Yield strength of wire is taken as $450 \mathrm{MPa}$

\section{Modelling}

In this study, ANSYS Explicit Dynamics is used for analytical work. The size Ferrocement panels modelled is $(500 \times 500) \mathrm{mm}$. The thicknesses of panels are taken as $15 \mathrm{~mm}$, $20 \mathrm{~mm}$ and $25 \mathrm{~mm}$.

The number of wire-meshes for $15 \mathrm{~mm}$ thick panels are 2 and 3, for $20 \mathrm{~mm}$ panel are 2,3 and 4 , for $25 \mathrm{~mm}$ panel are 3, 4 and 5 . The wire meshes are placed at cover of $5 \mathrm{~mm}$ both from top and bottom.

The diameter of wire mesh is $1.2 \mathrm{~mm}$. The square wires mesh is modelled such that the centre to centre spacing between two wires is $15 \mathrm{~mm}$ in both directions. The wire meshes are defined as reinforcement by assigning body interaction while modelling. ANSYS Design Modeller is used to model. An Avtomat Kalashnikov (AK-47) bullet is modelled for the analysis. The conical shape of bullet has diameter starting from $0 \mathrm{~mm}$ at bottom to $7.76 \mathrm{~mm}$ at top. The length of bullet is $39 \mathrm{~mm}$.

After making of model, the materials are assigned. As bullet is treated as rigid materials, the deformation and stresses in bullet are got neglected. The bottom edges of panels are assigned as fixed supports. Velocity and direction are assigned to bullet as per the requirement.

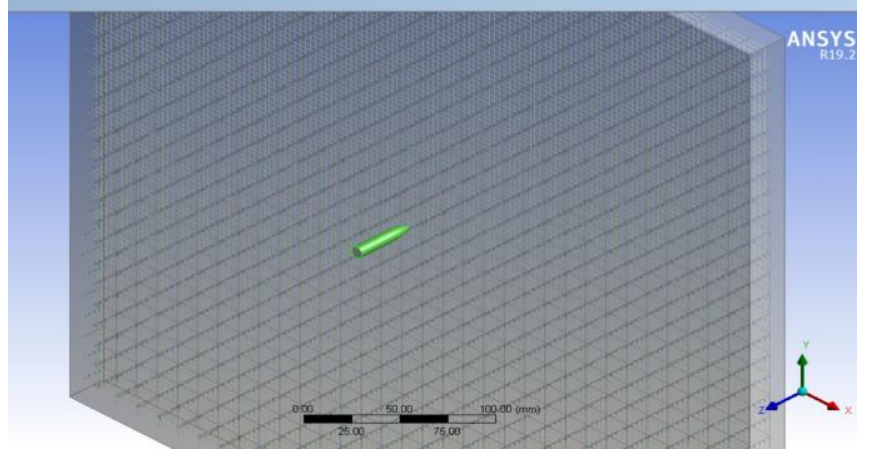

Fig. 1: Modelling High Impact Analysis Setup

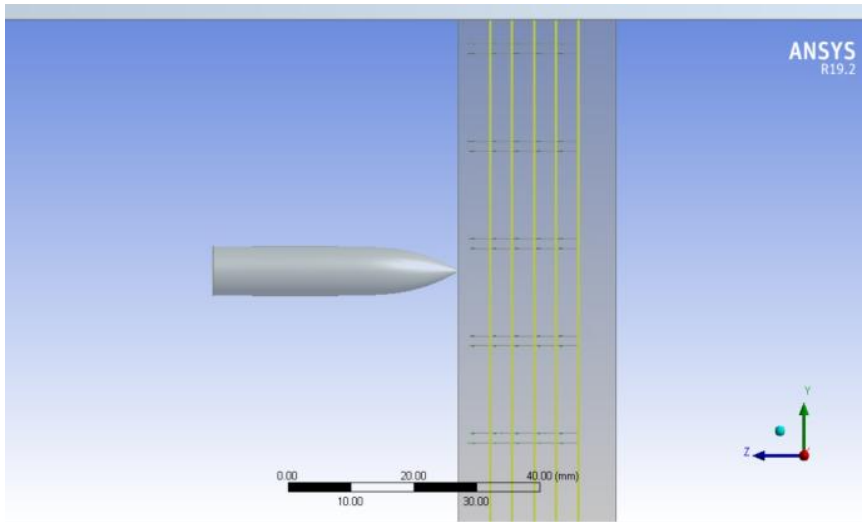

Fig. 2: Cross section showing wire-mesh layers

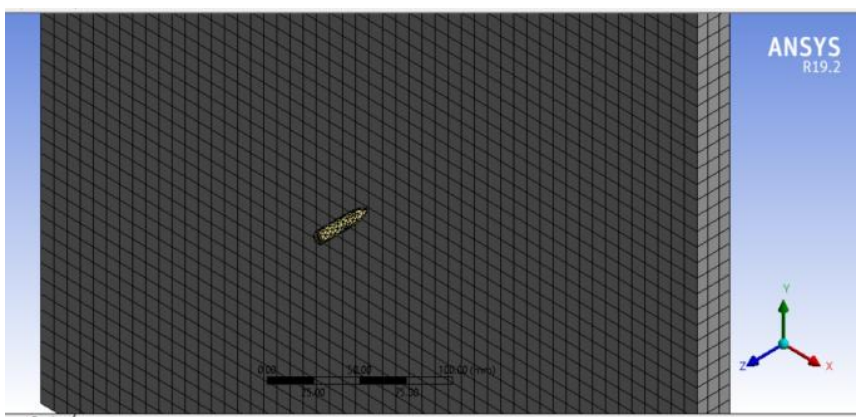

Fig. 3: Meshing of element

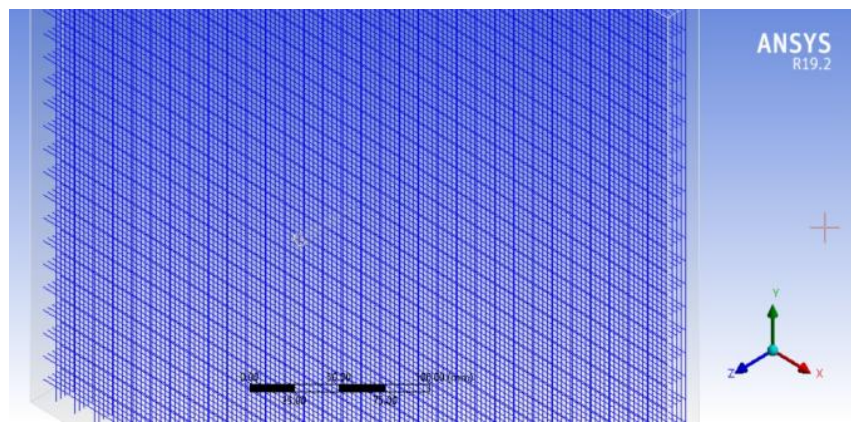

Fig. 4: Wire-mesh as reinforcement 


\section{Ferrocement Panels under High Velocity Impact by Incorporating Waste Foundry Sand}

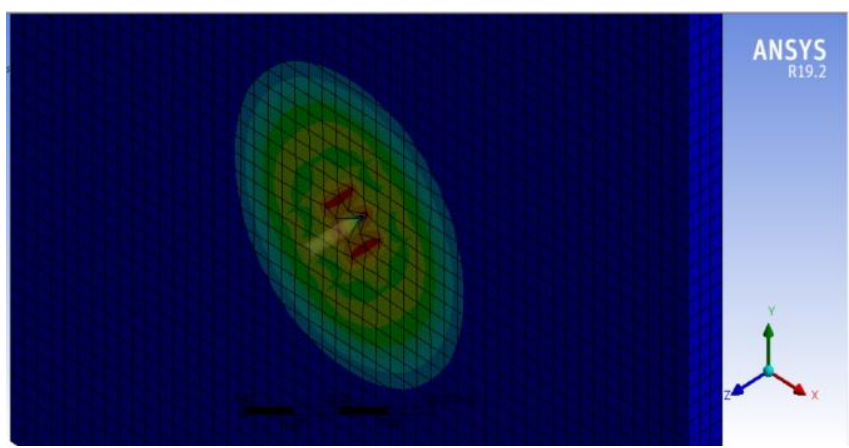

Fig. 5: Equivalent Stress on panel

\section{Explicit Dynamics Analysis in ANSYS 19.2}

The ANSYS explicit dynamics suite enables you to capture the physics of short-duration events for products that undergo highly nonlinear, transient dynamic forces.

With ANSYS, you'll gain insight into how a structure responds when subjected to severe loadings. Algorithms supported first principles accurately predict complex responses, like large material deformations and failure, interactions between bodies, and fluids with rapidly changing surfaces.

An explicit dynamics analysis is employed to work out the dynamic response of a structure thanks to stress wave propagation, impact or rapidly changing time-dependent loads. Momentum exchange between moving bodies and inertial effects are usually important aspects of the sort of study being conducted. This type of study also can be wont to model mechanical phenomena that are highly nonlinear. Nonlinearities may stem from the materials, (for example, hyper elasticity, plastic flows, failure) and from contact (for example, high speed collisions and impact). Events with time scales of less than 1 second (usually of order 1 millisecond) are efficiently simulated with this type of analysis.

\section{RESULTS OF ANALYTICAL WORK}

Various Ferrocement models are made by varying parameters such as thickness, number of mesh layers and waste foundry sand. This Models are analyzed for high velocity impact testing for which the velocities ranges from $150 \mathrm{~m} / \mathrm{s}$ to $750 \mathrm{~m} / \mathrm{s}$ increased by $100 \mathrm{~m} / \mathrm{s}$ for each model. as follows:

WFS: - Waste Foundry Sand. displacement of ferrocement panel of size $(500 \times 500) \mathrm{mm}$ with conventional mortar for various number of steel mesh layers with thickness $15 \mathrm{~mm}$, $20 \mathrm{~mm}$ and $25 \mathrm{~mm}$ respectively. (500x500x15) mm plate with 2 wire-mesh layers was reduced to $7.38 \mathrm{~mm}$ from $7.74 \mathrm{~mm}$ after replacing $30 \%$ fine aggregate with waste foundry sand. Similarly, for 3 wire-mesh layers, the deformation was reduced to $7.29 \mathrm{~mm}$ from $7.70 \mathrm{~mm}$ after replacing 30\% fine aggregate with waste foundry sand.

From same graph 1, The deformation of ferrocement panel for 2 wire-mesh layers was $7.74 \mathrm{~mm}$ which is further reduced to $7.70 \mathrm{~mm}$ for 3 wire-mesh layers. Similarly, the deformation of ferrocement panels with waste foundry sand was reduced to $7.29 \mathrm{~mm}$ for 3 wire-mesh layers from $7.38 \mathrm{~mm}$ for 2 wire-mesh layers.
Notations used to define various Ferrocement panels are

Graph 1, Graph 2 and Graph 3 shows the variation in

From graph 1 we can see that, the deformation for

Such similar variations in deformation due to replacement of $30 \%$ fine aggregate by waste foundry sand and number of mesh layers are shown in Graph 2 and Graph 3 for ferrocement panels with thickness $20 \mathrm{~mm}$ and $25 \mathrm{~mm}$ respectively.

Graph 4, Graph 5 and Graph 6 shows the variation in equivalent stress of ferrocement panel of size (500x500) mm with conventional mortar for various number of steel mesh layers with thickness $15 \mathrm{~mm}, 20 \mathrm{~mm}$ and $25 \mathrm{~mm}$ respectively.

From graph 4 we can see that, the equivalent stress for (500x500x15) mm plate with 2 wire-mesh layers was reduced to $477 \mathrm{MPa}$ from $494 \mathrm{MPa}$ after replacing $30 \%$ fine aggregate with waste foundry sand. Similarly, for 3 wire-mesh layers, the equivalent stress was reduced to $455 \mathrm{MPa}$ from $489 \mathrm{MPa}$ after replacing $30 \%$ fine aggregate with waste foundry sand.

From same graph 4 , The equivalent stress of ferrocement panel for 2 wire-mesh layers was 494MPa which is further reduced to $489 \mathrm{MPa}$ for 3 wire-mesh layers. Similarly, the equivalent stress of ferrocement panels with waste foundry sand was reduced to $455 \mathrm{MPa}$ for 3 wire-mesh layers from 477MPa for 2 wire-mesh layers.

Such similar variations in equivalent stress due to replacement of $30 \%$ fine aggregate by waste foundry sand and number of mesh layers are shown in Graph 5 and Graph 6 for ferrocement panels with thickness $20 \mathrm{~mm}$ and $25 \mathrm{~mm}$ respectively.

Table 2. Deformations and Equivalent stresses on (500x500x15) mm Ferrocement panel.

\begin{tabular}{|c|c|c|c|c|c|}
\hline \multirow{2}{*}{$\begin{array}{l}\text { Sr. } \\
\text { No. }\end{array}$} & \multirow{2}{*}{$\begin{array}{l}\text { Veloc } \\
\text { ity } \\
(\mathrm{m} / \mathrm{s})\end{array}$} & \multicolumn{2}{|l|}{2 layers } & \multicolumn{2}{|l|}{3 Layers } \\
\hline & & $\begin{array}{l}\text { Deformat } \\
\text { ion } \\
(\mathrm{mm})\end{array}$ & $\begin{array}{l}\text { Stress } \\
(\mathrm{MPa})\end{array}$ & $\begin{array}{l}\text { Deformatio } \\
\mathrm{n} \\
(\mathrm{mm})\end{array}$ & $\begin{array}{l}\text { Stress } \\
(\mathrm{MPa})\end{array}$ \\
\hline 1. & 150 & 1.54 & 83 & 1.54 & 82 \\
\hline 2. & 250 & 2.61 & 148 & 2.60 & 147 \\
\hline 3. & 350 & 3.71 & 223 & 3.70 & 221 \\
\hline 4. & 450 & 4.66 & 280 & 4.64 & 278 \\
\hline 5. & 550 & 5.61 & 344 & 5.59 & 341 \\
\hline 6. & 650 & 6.64 & 414 & 6.60 & 410 \\
\hline 7. & 750 & 7.74 & 494 & 7.70 & 489 \\
\hline
\end{tabular}

Table 3. Deformations and Equivalent stresses on (500x500x20) mm Ferrocement panel.

\begin{tabular}{|c|c|c|c|c|c|c|c|}
\hline \multirow{2}{*}{$\begin{array}{l}\text { S } \\
\text { r. } \\
\mathrm{N} \\
\mathrm{o}\end{array}$} & \multirow[b]{2}{*}{$\begin{array}{l}\text { Vel } \\
\text { ocit } \\
y \\
(\mathrm{~m} / \mathrm{s} \\
)\end{array}$} & \multicolumn{2}{|c|}{2 layers } & \multicolumn{2}{|c|}{3 Layers } & \multicolumn{2}{|l|}{4 layers } \\
\hline & & $\begin{array}{l}\text { Defor } \\
\text { matio } \\
\mathrm{n} \\
(\mathrm{mm})\end{array}$ & $\begin{array}{l}\text { Stre } \\
\text { SS } \\
(\mathrm{M} \\
\mathrm{Pa})\end{array}$ & $\begin{array}{l}\text { Deform } \\
\text { ation } \\
(\mathrm{mm})\end{array}$ & $\begin{array}{l}\text { Stre } \\
\text { ss } \\
(\mathrm{M} \\
\mathrm{Pa})\end{array}$ & $\begin{array}{l}\text { Deform } \\
\text { ation } \\
(\mathrm{mm})\end{array}$ & $\begin{array}{l}\text { Stre } \\
\text { ss } \\
\text { (MP } \\
\text { a) }\end{array}$ \\
\hline 1. & 150 & 1.27 & 75 & 1.26 & 73 & 1.13 & 61 \\
\hline 2. & 250 & 2.14 & 132 & 2.13 & 126 & 1.91 & 101 \\
\hline 3. & 350 & 3.06 & 196 & 3.04 & 188 & 2.71 & 142 \\
\hline 4. & 450 & 3.87 & 250 & 3.98 & 254 & 3.55 & 190 \\
\hline 5. & 550 & 4.57 & 294 & 4.55 & 288 & 4.44 & 253 \\
\hline 6. & 650 & 5.29 & 340 & 5.23 & 323 & 5.26 & 308 \\
\hline 7. & 750 & 6.06 & 392 & 5.95 & 370 & 6.03 & 366 \\
\hline
\end{tabular}


Table 4. Deformations and Equivalent stresses on (500x500x25) mm Ferrocement panel.

\begin{tabular}{|c|c|c|c|c|c|c|c|}
\hline \multirow[b]{2}{*}{$\mathrm{N}$} & \multirow[b]{2}{*}{$\begin{array}{l}\text { Vel } \\
\text { ocit } \\
y \\
(\mathrm{~m} / \mathrm{s} \\
)\end{array}$} & \multicolumn{2}{|c|}{3 layers } & \multicolumn{2}{|l|}{4 Layers } & \multicolumn{2}{|l|}{5 layers } \\
\hline & & $\begin{array}{l}\text { Defor } \\
\text { matio } \\
\mathrm{n} \\
(\mathrm{mm})\end{array}$ & $\begin{array}{l}\text { Stre } \\
\text { ss } \\
(\mathrm{M} \\
\mathrm{Pa})\end{array}$ & $\begin{array}{l}\text { Deform } \\
\text { ation } \\
(\mathrm{mm})\end{array}$ & $\begin{array}{l}\text { Stre } \\
\text { Ss } \\
(\mathrm{M} \\
\mathrm{Pa})\end{array}$ & $\begin{array}{l}\text { Deform } \\
\text { ation } \\
(\mathrm{mm})\end{array}$ & $\begin{array}{l}\text { Stre } \\
\text { ss } \\
\text { (MP } \\
\text { a) }\end{array}$ \\
\hline 1. & 150 & 1.58 & 100 & 1.56 & 93 & 1.39 & 61 \\
\hline 2. & 250 & 2.67 & 153 & 2.63 & 144 & 2.37 & 103 \\
\hline 3. & 350 & 3.77 & 208 & 3.71 & 195 & 3.38 & 147 \\
\hline 4. & 450 & 5.37 & 223 & 4.51 & 214 & 4.44 & 193 \\
\hline 5. & 550 & 5.58 & 237 & 5.28 & 235 & 5.44 & 236 \\
\hline 6. & 650 & 6.21 & 284 & 6.12 & 278 & 6.28 & 277 \\
\hline 7. & 750 & 7.17 & 334 & 7.04 & 325 & 7.17 & 317 \\
\hline
\end{tabular}

Table 5. Deformations and Equivalent stresses on (500x500x15) $\mathrm{mm}$ Ferrocement panel with waste foundry sand.

\begin{tabular}{|c|c|c|c|c|c|}
\hline \multirow{2}{*}{$\begin{array}{l}\text { Sr. } \\
\text { No. }\end{array}$} & \multirow{2}{*}{$\begin{array}{l}\text { Veloc } \\
\text { ity } \\
(\mathrm{m} / \mathrm{s})\end{array}$} & \multicolumn{2}{|l|}{2 layers } & \multicolumn{2}{|l|}{3 Layers } \\
\hline & & $\begin{array}{l}\text { Deformat } \\
\text { ion } \\
(\mathrm{mm})\end{array}$ & $\begin{array}{l}\text { Stress } \\
(\mathrm{MPa})\end{array}$ & $\begin{array}{l}\text { Deformatio } \\
\mathrm{n} \\
(\mathrm{mm})\end{array}$ & $\begin{array}{l}\text { Stress } \\
(\mathrm{MPa})\end{array}$ \\
\hline 1. & 150 & 1.54 & 79 & 1.54 & 76 \\
\hline 2. & 250 & 2.61 & 140 & 2.60 & 134 \\
\hline 3. & 350 & 3.71 & 211 & 3.70 & 201 \\
\hline 4. & 450 & 4.66 & 272 & 4.64 & 258 \\
\hline 5. & 550 & 5.61 & 332 & 5.59 & 317 \\
\hline 6. & 650 & 6.64 & 399 & 6.60 & 381 \\
\hline 7. & 750 & 7.74 & 477 & 7.70 & 455 \\
\hline
\end{tabular}

Table 6. Deformations and Equivalent stresses on (500x500x20) mm Ferrocement panel with waste foundry sand.

\begin{tabular}{|c|c|c|c|c|c|c|c|}
\hline \multirow{2}{*}{$\begin{array}{l}\text { S } \\
\text { r. } \\
\text { N } \\
\text { o. }\end{array}$} & \multirow[b]{2}{*}{$\begin{array}{l}\text { Vel } \\
\text { ocit } \\
y \\
(\mathrm{~m} / \mathrm{s} \\
)\end{array}$} & \multicolumn{2}{|c|}{2 layers } & \multicolumn{2}{|c|}{3 Layers } & \multicolumn{2}{|l|}{4 layers } \\
\hline & & $\begin{array}{l}\text { Defor } \\
\text { matio } \\
n \\
(\mathrm{~mm})\end{array}$ & $\begin{array}{l}\text { Stre } \\
\text { SS } \\
(\mathrm{M} \\
\mathrm{Pa})\end{array}$ & $\begin{array}{l}\text { Deform } \\
\text { ation } \\
(\mathrm{mm})\end{array}$ & $\begin{array}{l}\text { Stre } \\
\text { Ss } \\
(\mathrm{M} \\
\mathrm{Pa})\end{array}$ & $\begin{array}{l}\text { Deform } \\
\text { ation } \\
(\mathrm{mm})\end{array}$ & $\begin{array}{l}\text { Stre } \\
\text { ss } \\
\text { (MP } \\
\text { a) }\end{array}$ \\
\hline 1. & 150 & 1.27 & 70 & 1.26 & 64 & 1.13 & 58 \\
\hline 2. & 250 & 2.14 & 125 & 2.13 & 107 & 1.91 & 96 \\
\hline 3. & 350 & 3.06 & 186 & 3.04 & 150 & 2.71 & 136 \\
\hline 4. & 450 & 3.87 & 254 & 3.98 & 189 & 3.55 & 183 \\
\hline 5. & 550 & 4.57 & 289 & 4.55 & 218 & 4.44 & 242 \\
\hline 6. & 650 & 5.29 & 355 & 5.23 & 248 & 5.26 & 300 \\
\hline 7. & 750 & 6.06 & 385 & 5.95 & 278 & 6.03 & 357 \\
\hline
\end{tabular}

Table 7. Deformations and Equivalent stresses on (500x500x25) $\mathrm{mm}$ Ferrocement panel with waste foundry sand.

\begin{tabular}{|c|c|c|c|c|c|c|c|}
\hline \multirow[b]{2}{*}{$\begin{array}{l}\text { S } \\
\text { r. } \\
\text { N } \\
\text { o. }\end{array}$} & \multirow[b]{2}{*}{$\begin{array}{l}\text { Vel } \\
\text { ocit } \\
y \\
(\mathrm{~m} / \mathrm{s} \\
)\end{array}$} & \multicolumn{2}{|c|}{3 layers } & \multicolumn{2}{|l|}{4 Layers } & \multicolumn{2}{|l|}{5 layers } \\
\hline & & $\begin{array}{l}\text { Defor } \\
\text { matio } \\
n \\
(\mathrm{~mm})\end{array}$ & $\begin{array}{l}\text { Stre } \\
\text { ss } \\
(\mathrm{M} \\
\mathrm{Pa})\end{array}$ & $\begin{array}{l}\text { Deform } \\
\text { ation } \\
(\mathrm{mm})\end{array}$ & $\begin{array}{l}\text { Stre } \\
\text { ss } \\
(\mathrm{M} \\
\mathrm{Pa})\end{array}$ & $\begin{array}{l}\text { Deform } \\
\text { ation } \\
(\mathrm{mm})\end{array}$ & $\begin{array}{l}\text { Stre } \\
\text { ss } \\
\text { (MP } \\
\text { a) }\end{array}$ \\
\hline 1. & 150 & 1.58 & 88 & 1.56 & 81 & 1.39 & 66 \\
\hline 2. & 250 & 2.67 & 140 & 2.63 & 130 & 2.37 & 110 \\
\hline
\end{tabular}

\begin{tabular}{|l|l|l|l|l|l|l|l|}
\hline 3. & 350 & 3.77 & 194 & 3.71 & 181 & 3.38 & 156 \\
\hline 4. & 450 & 5.37 & 213 & 4.51 & 205 & 4.44 & 192 \\
\hline 5. & 550 & 5.58 & 239 & 5.28 & 234 & 5.44 & 230 \\
\hline 6. & 650 & 6.21 & 280 & 6.12 & 276 & 6.28 & 267 \\
\hline 7. & 750 & 7.17 & 331 & 7.04 & 324 & 7.17 & 307 \\
\hline
\end{tabular}




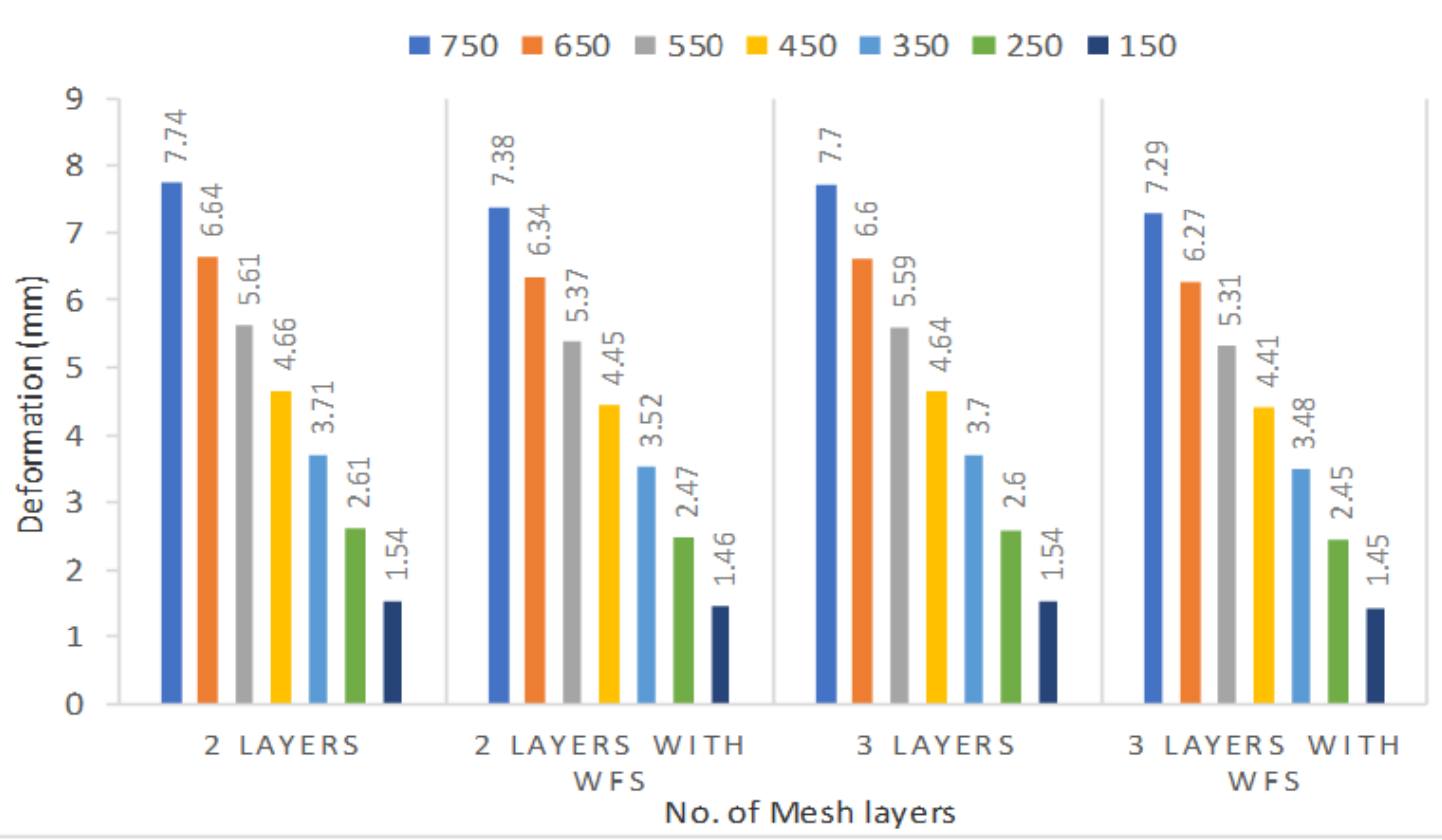

Graph 1: Deformation in (mm) For 15mm thick Ferrocement Panel.

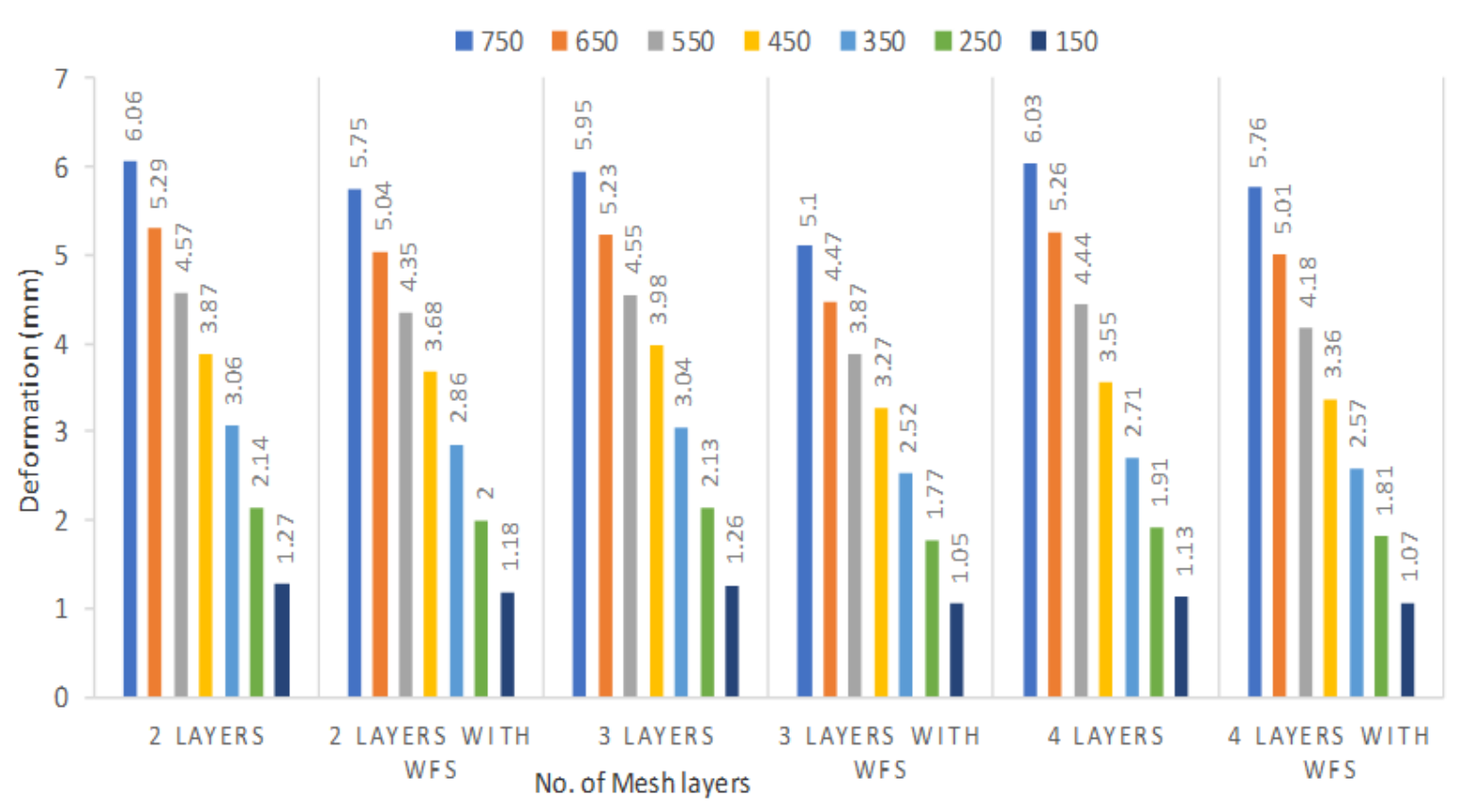

Graph 2: Deformation in (mm) For 20mm thick Ferrocement Panel 


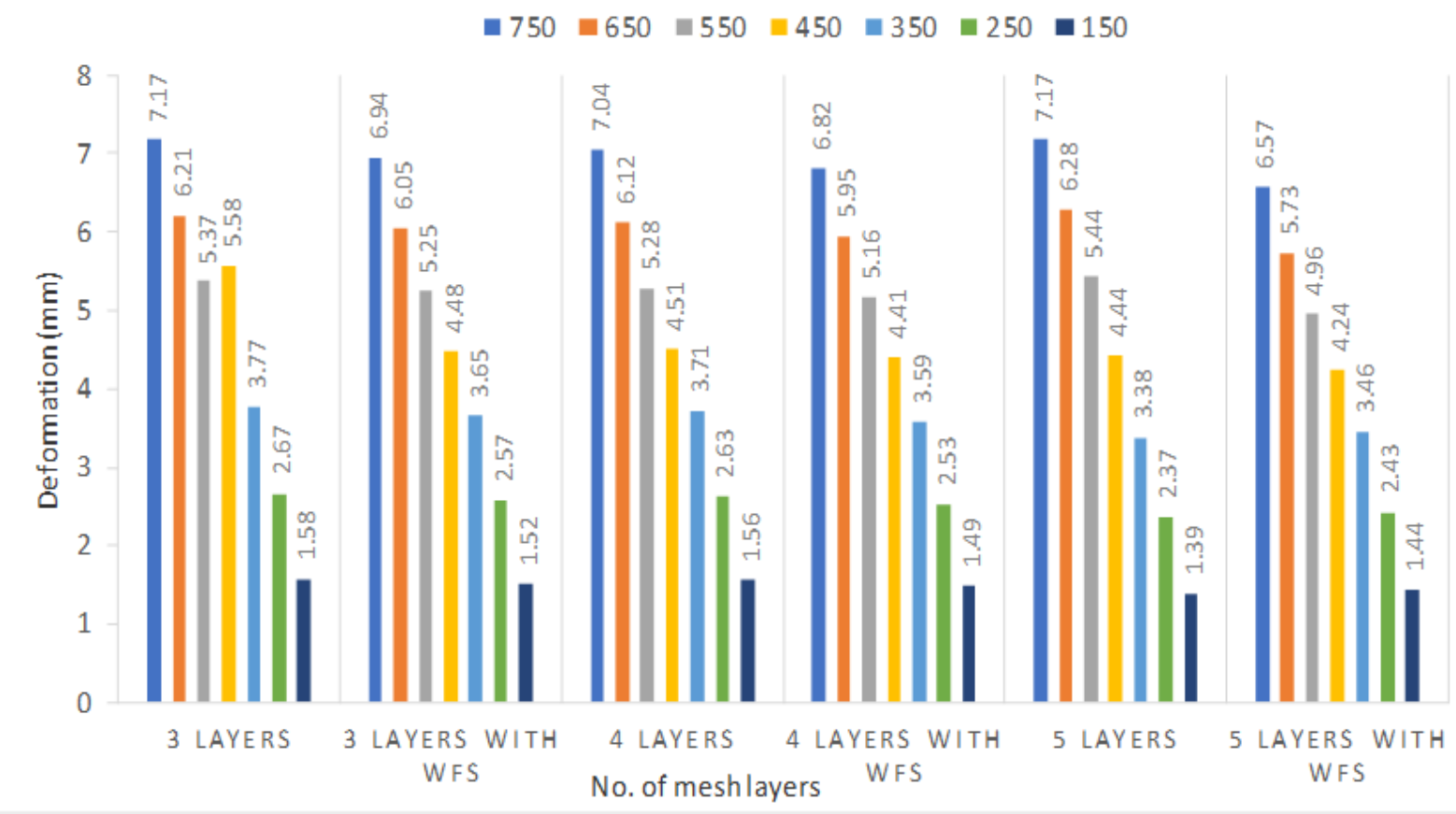

Graph 3: Deformation in (mm) For 25mm thick Ferrocement Panel

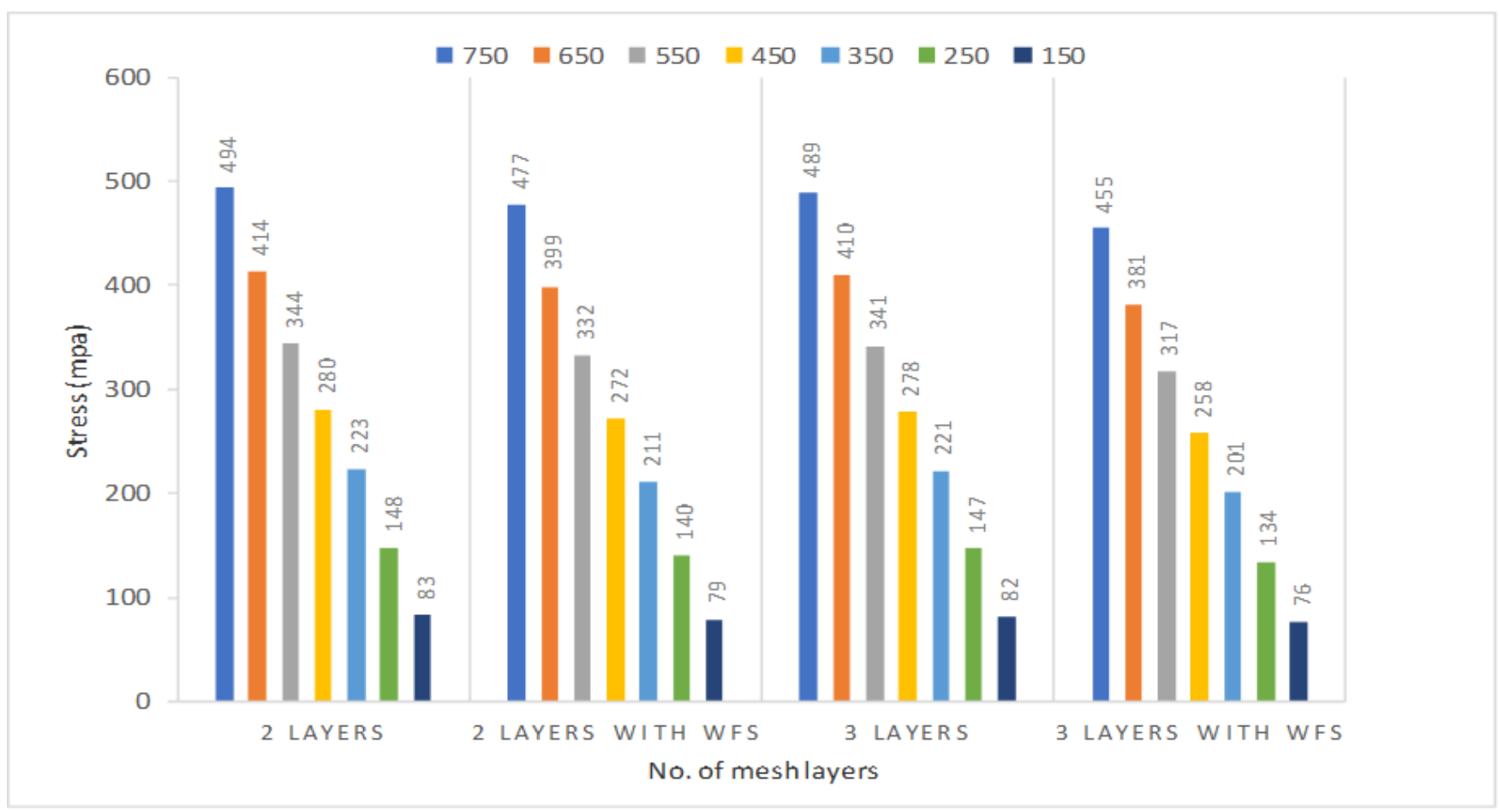

Graph 4: Equivalent Stress in (MPa) For 15mm thick Ferrocement Panel 


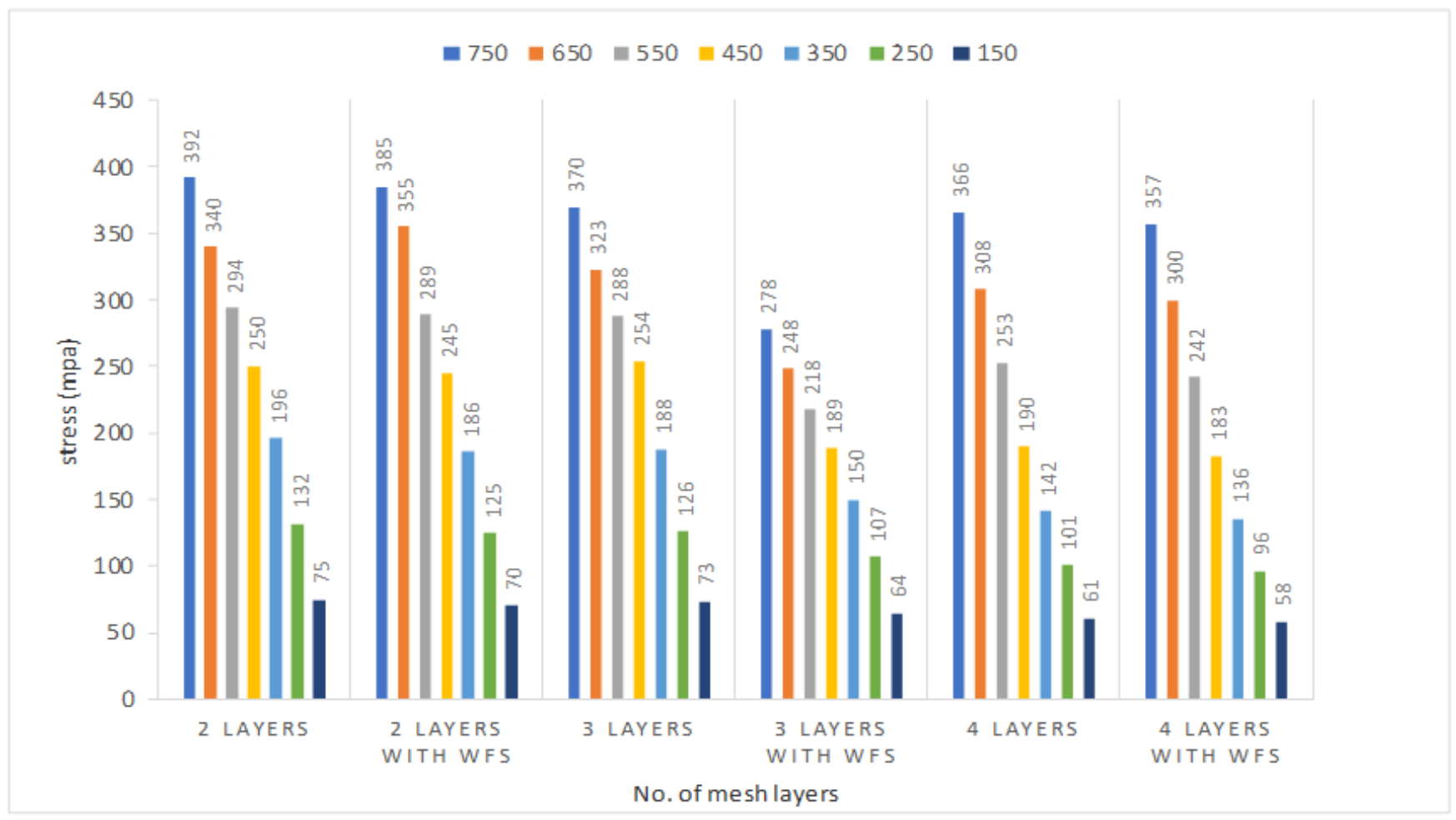

Graph 5: Equivalent Stress in (MPa) for 20mm thick Ferrocement Panel.

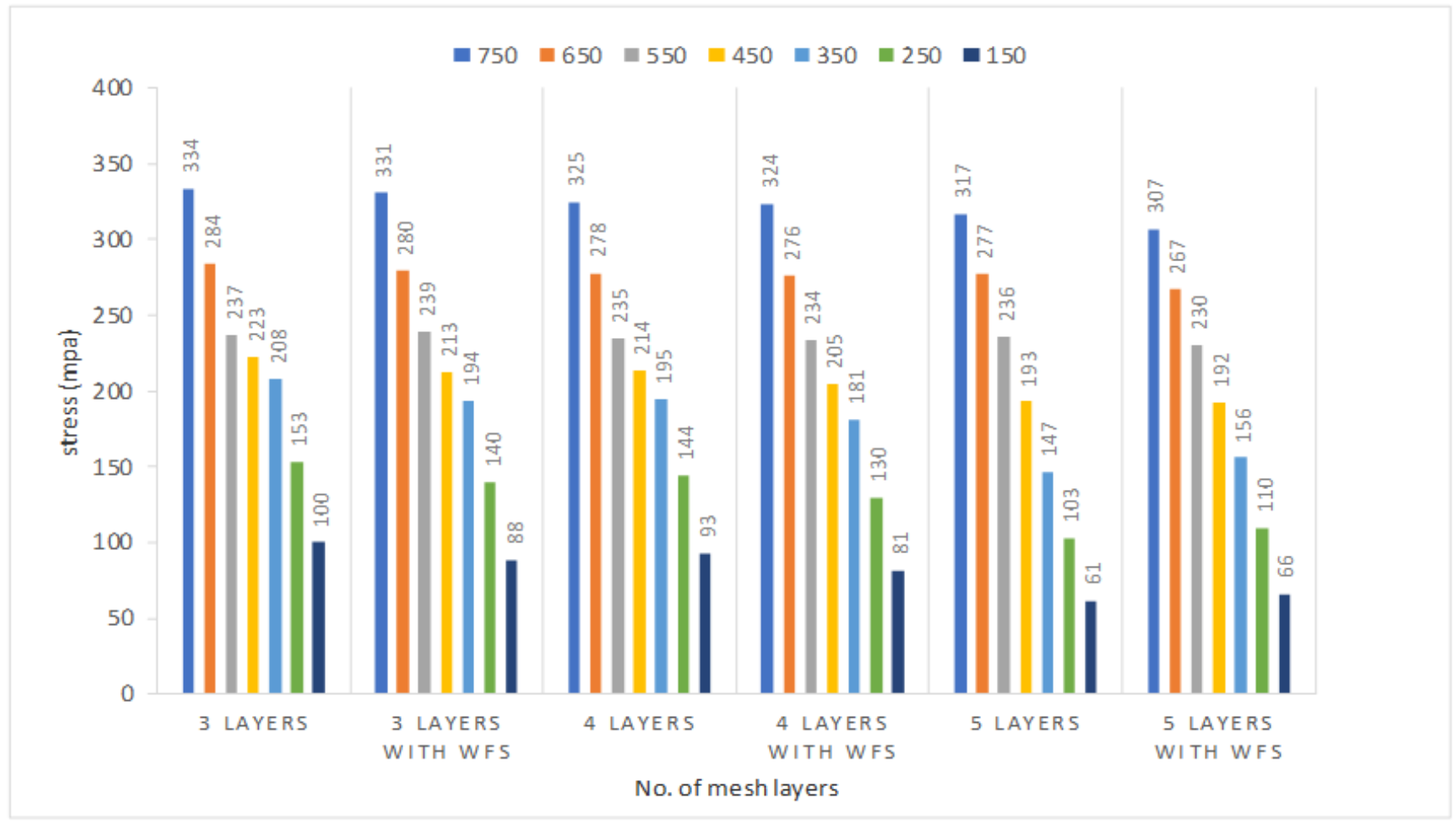

Graph 6: Equivalent Stress in (MPa) for $25 \mathrm{~mm}$ thick Ferrocement Panel

\section{CONCLUSION}

In high velocity impact loading by AK-47 bullet,

- The equivalent stress of $15 \mathrm{~mm}$ thick panel is $30 \%$ more than $20 \mathrm{~mm}$ thick panels using 2 layers of woven mesh for M30 grade of mortar while the equivalent stress of $20 \mathrm{~mm}$ thick panel is $20 \%$ more than $25 \mathrm{~mm}$ thick panels using 2 layers of woven mesh for M30 grade of mortar

- The reduction is observed in the penetration depths in ferrocement panels with waste foundry sand as compared with normal ferrocement panels. 
- The reduction observed in the equivalent stress is $08-10 \%$ in 4 layered wire-mesh as compared with 3 layered wire-mesh for $20 \mathrm{~mm}$ thick panel.

- Penetration depths, Equivalent stresses and normal stresses increases with increase in velocity of bullet.

- Increase in thickness of ferrocement panel and number of wire mesh layers resulted in decrease in penetration depths, Equivalent (von mises) stresses and normal stresses.

- Penetration depths, Equivalent (von mises) stresses and normal stresses are decreases in ferrocement panels by replacing fine aggregate by waste foundry sand.

\section{REFERENCES}

1. M. Sowmya and J. D. C. Kumar, "MIXING OF WASTE FOUNDRY SAND IN CONCRETE,” 2015.

2. R. Roy and V. Sairam, "Effect of Silica Fume and Foundry waste sand on strength characteristics of Geogrid and Ferro cement panel," in Materials Today: Proceedings, 2019, vol. 7, no. March, pp. 362-372.

3. P. J. P. Vipul D. Prajapati, Nilay Joshi, "Research Paper USED FOUNDRY SAND : OPPORTUNITIES FOR DEVELOPING OF LOW COST RIGID PAVEMENT Address for Correspondence," vol. II, no. Iii, 2013.

4. S. S. Jadhav, S. N. Tande, and A. C. Dubal, "Beneficial reuse of waste foundry sand in concrete," Int. J. Sci. Res. Publ., vol. 7, no. 3, pp. 74-95, 2017.

5. D. G. Gaidhankar, M. S. Kulkarni, and A. Akhtar, "Behaviour of Ferrocement Panel under Impact Loading,” vol. 7, no. 7, pp. 1-11, 2018.

6. K. Takiguchi, K. Nishimura, and S. Hori, "Behavior of Ferrocement Subjected to Missile Impact," Seven, no. SMiRT 17, pp. 1-6, 2003.

7. I. M. Kamal and E. M. Eltehewy, "Projectile penetration of reinforced concrete blocks: Test and analysis," Theor. Appl. Fract. Mech., vol. 60, no. 1, pp. 31-37, 2012.

8. M. H. Zhang, V. P. W. Shim, G. Lu, and C. W. Chew, "Resistance of high-strength concrete to projectile impact," Int. J. Impact Eng., vol. 31, no. 7, pp. 825-841, 2005.

9. A. A. Ismail Al-Hadithi, K. Ibrahim Aziz, and M. Tarrad Nawar Al-Dulaimi, "Behaviour of ferrocement slabscontaining SBR under impact loads," Int. J. Sustain. Green Energy, vol. 4, no. 4, pp. 3-1, 2015.

\section{AUTHORS PROFILE}

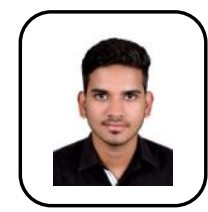

Balraj E. Karpe got his bachelor of engineering of degree in Civil Engineering from R. H. Sapat College of engineering, Nashik in 2017. He is pursuing his Master of Technology in Structural Engineering at MIT-World Peace University, Pune-Maharashtra. Email: balrajkarpe1@gmail.com

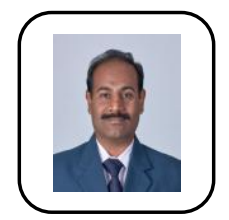

Prof. Darshan G. Gaidhankar is associate professor at School of Civil Engineering at MIT-WPU. He has completed his master of technology in structural engineering and right now pursuing his Ph.D. He has total 18 years of teaching experience and 1.5 years of Industrial experience. Email: darshan.gaidhankar@mitwpu.edu.in

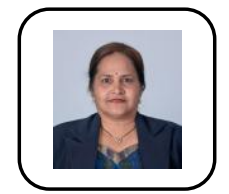

Prof. Dr. Mrudula S. Kulkarni is professor at the School of Civil Engineering at MIT World Peace University and heading this school since its inception. Prior to this, she was Professor and Head of School of Structural Engineering at MIT WPU, Pune. Earlier she did her doctoral research at College of Engineering Pune, Pune University, in the field of Bio Mechanics under the guidance of Dr. Satish Sathe and Dr. K. H. Sancheti.

Email: mrudula.kulkarni@mitwpu.edu.in 